\section{George Vander Voort selected as Top Consultant of the Decade by IAOTP}

\section{George F Vander Voort, President \& Consultant of Vander Voort Consulting and Consultant for Buehler Ltd., was recently chosen as the Top Consultant of the Decade for 2021 given by the International Association of Top Profes- sionals (IAOTP).}

While inclusion with the International Association of Top Professionals is an honor in itself, only 1 Consultant in Metallurgical Services is selected for this distinction. Mr. Vander Voort is being recognized for dedicating over five decades of his professional experience to Metallography and Materials Science. He will receive this award at IAOTP's 2021 Annual Awards Gala being held at the Plaza Hotel in NYC this December. Furthermore, Mr. Vander Voort will be honored for his 2020 selection as a Lifetime Achievement recipient. IAOTP is incredibly honored to recognize Mr. Vander Voort for all of his success and accomplishments. www.iaotp. com/award-gala

Stephanie Cirami, the President of the International Association of Top Professionals stated "Choosing Mr. Vander Voort for this most recent distinction was an easy decision for our panel to make. His dedication of time to his industry, his passion for education within his field and his extraordinary knowledge of Metallography prove he is truly deserving of such an honor. We hope to spend time with him at the 2021 Annual Awards Gala and we look forward to celebrating his merits."
Before beginning his professional career path, Mr. Vander Voort received his Bachelor of Science in Metallurgical Engineering from Drexel Institute of Technology in 1967, and his Master of Science Degree in Metallurgy and Materials Science from Lehigh University in 1974.

Mr. Vander Voort is a talented and passionate, dynamic results-driven leader. He has demonstrated success not only as a Consultant and Specialist in all aspects of Metallographic Analysis \& Research, but with every position he has ever held. His impressive repertoire of other roles has included: Research Engineer for the Bethlehem Steel Corporation, Supervisor of Metal Physics, Materials Characterization \& Microstructural Analysis and Mechanical Testing for the Carpenter Technology Corporation, and Director for Research and Technology for Buehler Ltd. He taught physical metallurgy at Pennsylvania State University and was a visiting lecturer at the University of Canterbury in New Zealand. $\mathrm{He}$ is regarded by his peers as one of the world's most influential and best Metallurgical Research Engineers of his time. His textbook, Metallography: Principles and Practice, is used worldwide.

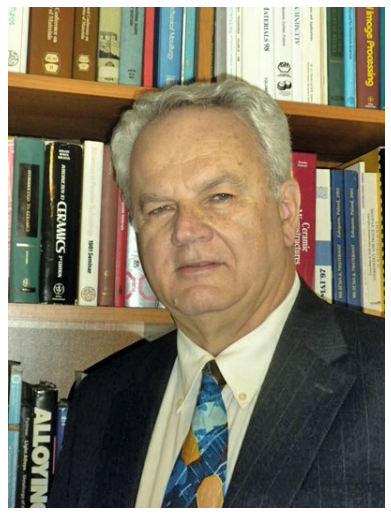

George is well-recognized for his work in failure analysis, both through publications and investigations. He was a major contributor to the ASM Handbook series volumes on Metallography and Microstructures, Fractography, Failure Analysis, and Materials Characterization. $\mathrm{He}$ is a court certified expert on failure analysis and has been involved in numerous cases. In 1993, he was requested by the Nuclear Regulatory Commission to review the microscopy studies on the lower head of the Three-Mile Island Unit 2 nuclear reactor which suffered a catastrophic accident in March 1979. The studies were performed by personnel at Argonne National Laboratory and at Idaho Falls National Engineering Laboratory. The review was prompted by disputes as to how hot, how close to melt down, the lower head got during the incident. George critiqued the work, obtained a set of specimens, and showed how the exposure temperatures could be determined with much higher precision using quantitative metallography and 


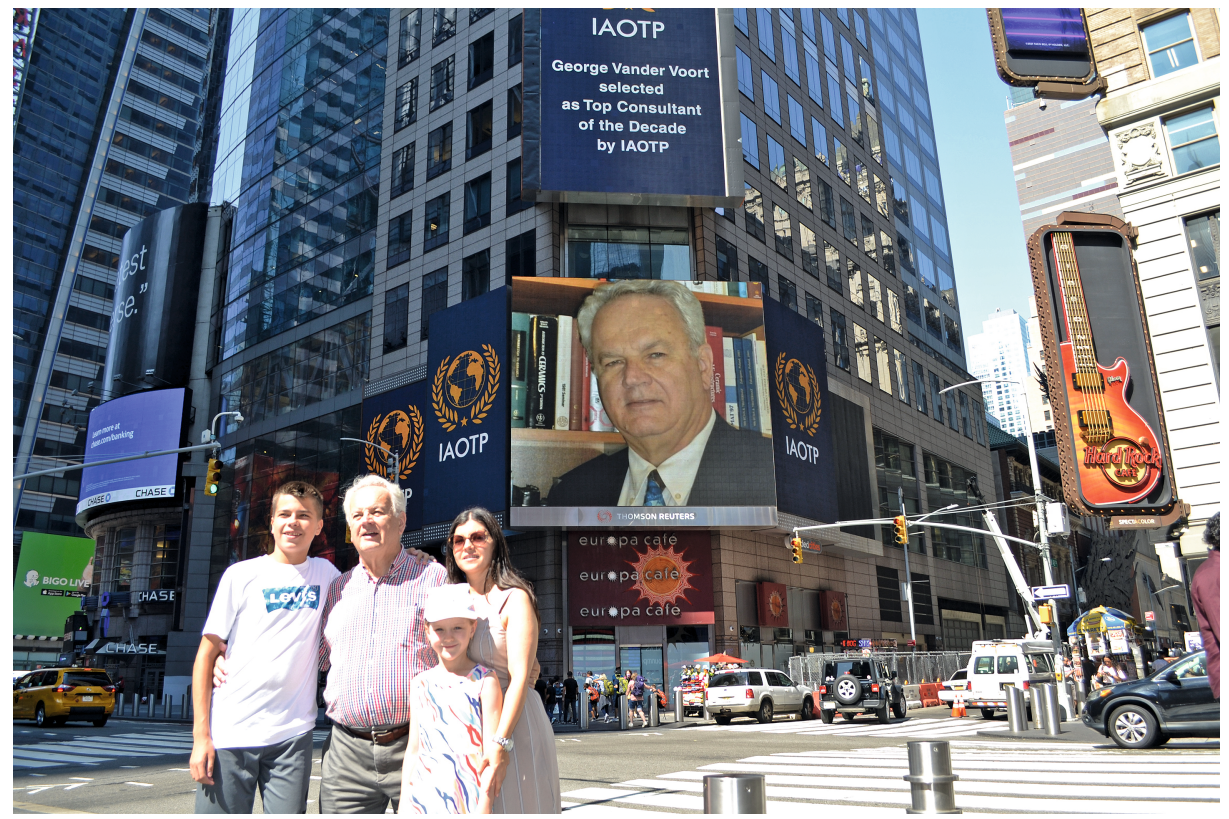

selective etching. More recently, he has worked with a FEMA board member and several faculty members at Worcester Polytechnic Institute to examine structural steel beams from building 7 and from buildings 1 and 2 of the World Trade Center after the 9/11/01 attack to determine why building 7 collapsed, as it was not impacted but only caught on fire from falling debris, and why the structural steel beams were so heavily attacked to perforation. George has also studied a number of failures involving semi-submersible oil exploration rigs and permanently installed drilling rigs in the Gulf of Mexico, pressure vessel failures, and soldered pipe joint failures. He studied a lampshade frame, covered by human skin and believed to have been made at the Buchenwald concentration camp, for Hoggard Films to determine when it was made. The 60-minute documentary made for National Geographic TV was broadcast on 29 September 2012.

Throughout his remarkable career, Mr. Vander Voort has received numerous awards and accolades and has been recognized worldwide for his outstanding leadership and commitment to the profession. This year he will be considered for an exclusive interview on TIP Radio. Last year he received the Distinguished Life Membership Award from ASM International and the prestigious IAOTP Lifetime Achievement Award. In 2019 he was honored as Top Consultant of the Year at IAOTP's Annual Awards Gala. In 2016 he received Drexel's Service to Our Profession Award and in 2005 he received Drexel's Distinguished Alumnus Award. He has been featured over 50 times in 16 editions of Who's Who in Science and Engineering, International Who's Who in Engineering, Who's Who in Technology Today, Who's Who in America, Who's Who in the East, Who's Who in Finance and Industry and Who's Who in the World. The September 2009 Issue of Practical Metallography was dedicated to George's $65^{\text {th }}$ Birthday. In 2008 he was named a Distinguished Life Member and Fellow of Alpha Sigma Mu honorary scholastic society for materials science majors and was elected to their board and served as Vice President from 2011-2015. In 2006 he received the Roland Mitsche prize of the Montanuniversitat Leoben, in Leoben, Austria 
for his contributions to metallography. In 2004, he received the IMS Henry Clifton Sorby Award. He received the Men of Achievement Distinction for three years, the ASTM Award of Merit (Fellow) in 1987, the ASM International Fellow Award in 1990 and the ASTM E-28 Anthony DeBellis Award for his contributions in hardness testing. In 1992 he received the Pierre A. Jacquet - Francis F. Lucas Grand Prize in Metallography, in 1993 he received the Bradley Stoughton Award of the Lehigh Valley Chapter of ASM International, and in 1994 he received the ASTM L.L. Wyman Memorial Award, just to name a few.

In addition to his successful career, Mr. Vander Voort is a sought-after lecturer, Keynote speaker, published author, contributor to many articles and has served on numerous boards and committees. He has given 457 lectures and 278 seminars in 42 countries, spoken 84 times at 52 ASM Chapters, and at 74 Universities. He is the principal author of 447 publications, edited 18 books, author of 32 articles in various editions of the ASM Metals Handbook Series, has made 11 videotapes in the ASM video course Principles of Metallography, is the author of 8 ASTM standards and holds 6 patents. Mr. Vander Voort's micrographs have been within or on the covers of over 180 books, magazines, newsletters, brochures or calendars. He has taught 87 one-week courses for ASM's Metals Engineering Institute, 117 courses for Buehler and 82 for other so- cieties, companies and universities. George is a member of the American Society for Metals and served on the executive committee of the Lehigh Valley Chapter, past member of the MEl and the Academy Committees, he chaired the Technical Books Committee and was secretary and vice chairman of Publications Council. Currently he is now on the Technical Books Committee, the Handbook Committee, the Events Committee and the International Committee. He is also a member of the American Society for Testing and Materials (ASTM) and was chairman of E.04.14 where he developed and wrote 8 standards for both manual and automated quantitative metallographic measurements. He also chaired three international symposia for ASTM E-4. George is also a member of the International Society for Stereology, an honorary member of the Polish Society for Stereology, and a member of Deutsche Gesellschaft für Materialkunde (German Materials Society) (just to name a few).

Looking back, Mr. Vander Voort attributes his success to his education, mentors he has had along the way and staying passionate in his research and work. He has two children. When not working, George enjoys foreign travel, food and wine, watercolor painting, photography, hiking and backpacking. His wife, Dr. Elena (Manilova) Vander Voort, is a physical metallurgist and electron microscopy expert on high-temperature alloys with 30 years of service at the Polzunov Central Boiler and Turbine Institute in St. Petersburg, Russia, in the failure analysis and life extension department. For the future, he hopes that his research and continuous efforts will enlighten and inspire people to pursue a career in this industry.

For more information on $\mathrm{Mr}$. Vander Voort please visit: www.georgevandervoort.com

\section{About IAOTP}

The International Association of Top Professionals (IAOTP) is an international boutique networking organization who handpicks the world's finest, most prestigious top professionals from different industries. These top professionals are given an opportunity to collaborate, share their ideas, be keynote speakers and to help influence others in their fields. This organization is not a membership that anyone can join. You have to be asked by the President or be nominated by a distinguished honorary member after a brief interview.

IAOTP's experts have given thousands of top prestigious professionals around the world the recognition and credibility that they deserve and have helped in building their branding empires. IAOTP prides itself to be a one of a kind boutique networking organization that hand picks only the best of the best and creates a networking platform that connects and brings these top professionals together.

For more information on IAOTP please visit: www.iaotp.com 


\section{The Biodegradable Battery}

The number of data-transmitting microdevices, for instance in packaging and transport logistics, will increase sharply in the coming years. All these devices need energy, but the amount of batteries would have a major impact on the environment. Empa researchers have developed a biodegradable mini-capacitor that can solve the problem. It consists of carbon, cellulose, glycerin and table salt. And it works reliably.

The fabrication device for the battery revolution looks quite unconspicuous: It is a modified, commercially available 3D printer, located in a room in the Empa laboratory building. But the real innovation lies within the recipe for the gelatinous inks this printer can dispense onto a surface. The mixture in question consists of cellulose nanofibers and cellulose nanocrystallites, plus carbon in the form of carbon black, graphite and activated carbon. To liquefy all this, the researchers use glycerin, water and two different types of alcohol. Plus a pinch of table salt for ionic conductivity.

\section{A sandwich of four layers}

To build a functioning supercapacitor from these ingredients, four layers are needed, all flowing out of the 3D printer one after the other: a flexible substrate, a conductive layer, the electrode and finally the electrolyte. The whole thing is then folded up like a sandwich, with the electrolyte in the center.

What emerges is an ecological miracle. The mini-capacitor from the lab can store electricity for hours and can already power a small digital clock. It components. can withstand thousands of charge and discharge cycles and years of storage, even in freezing temperatures, and is resistant to pressure and shock.

\section{Biodegradable power supply} Best of all, though, when you no longer need it, you could toss it in the compost or simply leave it in nature. After two months, the capacitor will have disintegrated, leaving only a few visible carbon particles. The researchers have already tried this, too.

"It sounds quite simple, but it wasn't at all," says Xavier
Aeby of Empa's Cellulose \& Wood Materials lab. It took an extended series of tests until all the parameters were right, until all the components flowed reliably from the printer and the capacitor worked. Says Aeby: "As researchers, we don't want to just fiddle about, we also want to understand what's happening inside our materials."

Together with his supervisor, Gustav Nyström, Aeby developed and implemented the concept of a biodegradable electricity storage device. Aeby studied microsystems engineering at EPFL and came to Empa for his doctorate. Nyström and his team have been investigating functional gels based on nanocellulose for some time. The material is not only an environmentally friendly, renewable raw material, but its internal chemistry makes it extremely versatile. "The project of a biodegradable

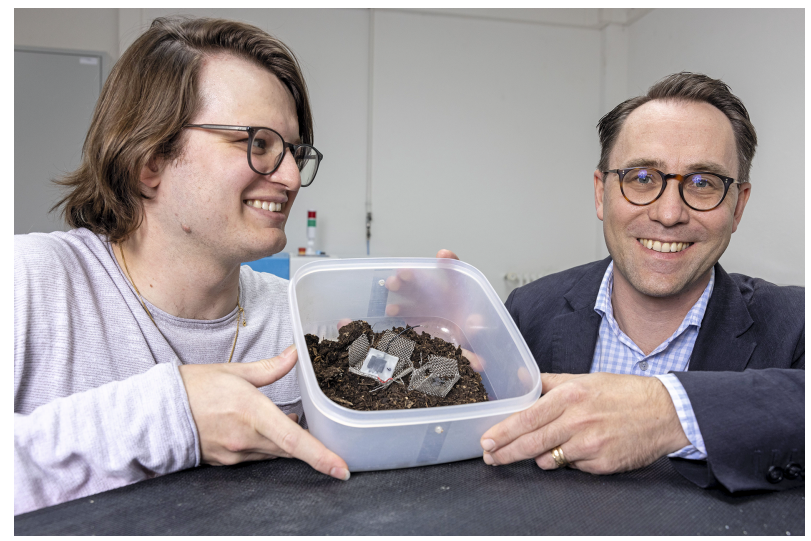

Xavier Aeby and Gustav Nyström invented a fully printed biodegradable battery made from cellulose and other non-toxic 


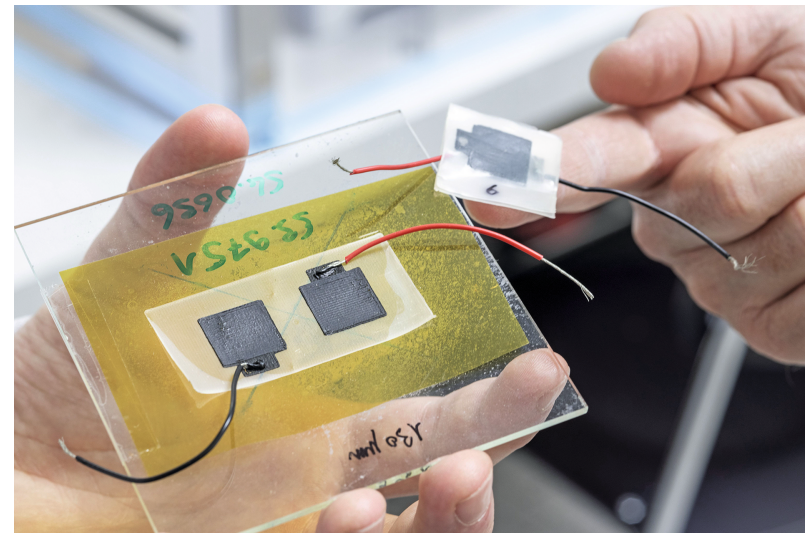

The biodegradable battery consists of four layers, all flowing out of a 3D printer one after the other. The whole thing is then folded up like a sandwich, with the electrolyte in the center.

electricity storage system has been close to my heart for a long time," Nyström says. "We applied for Empa internal funding with our project, Printed Paper Batteries, and were able to start our activities with this funding. Now we have achieved our first goal."

\section{Application in the Internet of Things}

The supercapacitor could soon become a key component for the Internet of Things, Nyström and Aeby expect. "In the future, such capacitors could be briefly charged using an electromagnetic field, for example, then they could provide power for a sensor or a microtransmitter for hours." This could be used, for instance, to check the contents of individual packages during shipping. Powering sensors in environmental monitoring or agriculture is also conceivable - there's no need to collect these batteries again, as they could be left in nature to degrade.

The number of electronic microdevices will also be increasing due to a much more widespread use of near-patient laboratory diagnostics ("point of care testing"), which is currently booming. Small test devices for use at the bedside or self-testing devices for diabetics are among them. "A disposable cellulose capacitor could also be well suited for these applications", says Gustav Nyström.

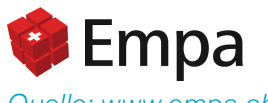

Quelle: www.empa.ch

We draw your attention to the fact that the individual pieces of information from the different sources will not be checked for accuracy. It is only possible to check for plausibility.
Wir weisen Sie darauf hin, dass die Nachrichten nicht auf ihre sachliche Richtigkeit, sondern nur auf Plausibilität überprüft werden.

\section{Bibliography}

DOI 10.1515/pm-2021-0059

Pract. Metallogr. 58 (2021) 10; page 672-677 (c) 2021 Walter de Gruyter $\mathrm{GmbH}$,

Berlin/Boston, Germany

ISSN 0032-678X · e-ISSN 2195-8599 